Date: 30 November 1994

\title{
Subject: Part-time Farmer is Killed After Losing Control of His Tractor
}

\begin{abstract}
SUMMARY
A 38-year-old part-time farmer (landowner) was killed after the tractor he was operating turned over on him. The victim was mowing his property using a tractor and rotary mower attachment. The tricycle-type tractor was not equipped with a rollover protective structure (ROPS) or a seat belt. After completing an upper field, he drove the tractor down a hill toward the public roadway. The brakes apparently failed and he lost control of the tractor. The tractor slid off the gravel road, turned over and came to rest on top of the victim. There were no witnesses to the event. In order to prevent similar occurrences, the FACE investigator concluded:
\end{abstract}

- Tractor owners and operators should equip tractors with rollover protection and seatbelts.

- Equipment should be kept in good working order.

- Part-time equipment operators should be trained in safe operation procedures.

\section{INTRODUCTION}

On August 1, 1994, the Kentucky FACE investigator learned of this fatality from a regional newspaper. On August 12, 1994, the FACE investigator traveled to the scene of the accident to conduct an investigation. The deputy coroner who handled the case and the responding sheriff were interviewed and both accompanied the investigator to the incident scene. The tractor and accident location were then photographed and a copy of the coroner's report was obtained. After completing the field investigation, FACE followed up with phone interviews with the victim's brother and EMS personnel.

The victim worked full-time at a tire manufacturing facility. He maintained a small farm where he periodically borrowed his brother's tractor and bush hog to keep weeds down. The victim's brother reported the victim had about 12 years experience operating the tractor. He also reported the victim to be a very private person in relatively good health.

\section{INVESTIGATION}

The following is surmised from the evidence and discussions with the coroner, the sheriff and the victim's brother. The day of the incident, the victim had borrowed his brother's tractor in order to mow his field. Access to the field was via a single-lane, tree lined, gravel roadway. The roadway sloped 8 degrees up toward the field. About 300 feet from the top of the hill the road curved to the left. At approximately 6:00 pm the day of the incident, the victim was mowing the last portions of his property. Having completed the field, the victim began his descent of the hill. Part way down the hill, the victim lost control as evidenced by the trail in the gravel. At the curve is a deep ravine along the right side. Evidence at the scene such as ruts in the gravel suggest the victim tried to slow the tractor by steering side to side as he progressed rapidly down the hill. As the victim lost control, the front wheels slid off the road causing the tractor to roll over at least one and a half 
times before coming to rest. The victim's right arm was pinned under the tractor's left fender. The turn over occurred about 80 feet from the public highway.

At approximately 8:00 pm, as a farmer in the area was driving to the county fair, he glanced up the private drive. He saw about a twelve inch section of the tractor front sticking up into the air. The two wheels were partly obscured by the hood of the tractor, but the color unmistakably identified the object as a tractor. The farmer then went to his house about 500 feet down the highway and called 911. An off-duty sheriff who lives in the area heard the call to EMS at 8:09 pm on the scanner and responded to the scene. He arrived at the scene at about 8:15. The sheriff checked for a pulse and felt none. The victim had no pulse or respiration when EMS personnel arrived at 8:18. The deputy coroner arrived at 9:20 and pronounced the victim dead. It was estimated the victim was trapped under the fender for about 30 minutes, but that death occurred when his neck broke on the first rollover.

The 1964 Allis Chalmers D-17 tricycle tractor was moderately damaged in the rollover. It was found upside down, not in gear and the engine off. Both fenders were crushed and the exhaust stacks were bent. The tractor is a drop bull gear type where the wheel center is below the transmission (high-profile type). Attached to the tractor along the sides of the engine were 50 gallon plastic irrigation barrels; one on each side. The barrel on the right side was crushed. The sheriff reported the fluid from the barrel leaked out when the tractor was upside down in the ravine.

When the investigator depressed the brakes, they went to the floor with no resistance. The clutch and steering appeared to work properly. The bush hog was not available at the time of investigation, however it was reported as a three point hitch type.

\section{CAUSE OF DEATH}

The cause of death was ruled as a fractured neck. An autopsy was not performed.

\section{RECOMMENDATIONS/ DISCUSSION}

Recommendation \#1: Tractor owners and operators should contact their county extension agent, local equipment dealer or equipment manufacturer to see if retro-fit rollover protection and operator restraint systems are available for this equipment.

Discussion \#1: The tractor in this incident, manufactured in 1964, was not equipped with a ROPS or an operator restraint system, which protects the operator in the event of a roll over. ROPS first became available as optional equipment on farm tractors in 1971. These safety features were not required on tractors until 1976, when OSHA Standard 29CFR 1928.51 went into effect. This standard required employers to provide ROPS and safety belts for all employee-operated tractors manufactured after October 25, 1976. However, this standard does not apply to family farms or farms employing fewer than 11 employees. Since 1985, as a result of voluntary agreements by tractor manufacturers, all new tractors sold in the US have been equipped with ROPS and safety belts. (MMWR Jan 29, 1993) On this 1964 tractor, retro-fit ROPS and operator-restraint systems are available. Tractor owners should contact dealers, manufacturers or county extension agents for information on sources of retrofit ROPS and operator restraint systems. ROPS are particularly important on tricycle type tractors since the inherent balance is less than on spread front wheel type tractors.

Recommendation \#2: Equipment should be kept in good working order. 
Discussion \#2: The brakes of the tractor were not functioning as they were designed. Brakes are used to slow a tractor as well as turn the tractor when used independently. In this case the slope of the hill caused the tractor to roll and gain momentum. Once the forward motion began it would not be possible to engage the transmission to slow the tractor. Since the incident was not witnessed, it is not known if the tractor was in gear as it rolled. It was found out of gear. Braking and using a low gear, the same gear used to ascend the hill, is recommended.

Recommendation \#3: Part-time farm equipment operators should be trained in safe operating procedures.

Discussion \#3: Injury prevention specialists knowledgeable in agricultural hazards should offer classes related to tractor safety and handling. In this case the victim had no formal training on the equipment nor did he operate the equipment on a daily basis. Offering a course in the evening where individuals who held other full-time jobs could attend may reduce the risk of fatal injury. Making the class accessible to the part-time farmer/equipment operator is paramount. As well, incentives for participation may facilitate attendance.

\section{REFERENCES}

Standard Number 1928.51 Subpart C US Department of Labor Occupational Safety and Health Administration, OSHA CD-ROM (OSHA A94-2) February 1994.

Effectiveness of Roll Over Protective Structures for Preventing Injuries Associated with Agricultural Tractors. MMWR 42(03); 57-59.

National Safety Council (1978). "Tractor Operation and Roll-Over Protective Structures." Occupational Safety \& Health Data Sheets. I-622-Reaf. 85.

National Institute for Occupational Safety and Health (Jan 29, 1993). "NIOSH Reports on the Preventability of Tractor Rollovers." Centers for Disease Control and Prevention. DHHS (NIOSH) publication No. 93-119. 